\title{
Characteristics of patient with chronic hepatitis $b$ from a community hospital in North Brooklyn
}

\author{
Dalia Mahmoud ${ }^{1,2,3 *}$, Priyanka Yerragorla ${ }^{3}$, Ahmed Shady $^{3}$, Ben Shamian ${ }^{4}$ and Nora V Bergasa ${ }^{3}$ \\ 1Division of Gastroenterology, NYC Health+Hospitals, Woodhull, Brooklyn, NY, USA \\ ${ }^{2}$ Division of Gastroenterology, NYC Health+Hospitals, Metropolitan and PAGNY, NY, USA \\ ${ }^{3}$ Department of Medicine, NYC Health+Hospitals, Metropolitan and PAGNY, NY, USA \\ ${ }^{4}$ Department of Critical Care Medicine, Maimonides Medical Center, Brooklyn, NY, USA
}

\begin{abstract}
Introduction: The estimated prevalence of chronic hepatitis B virus infection is $0.3-0.5 \%$ in the United States, in contrast to that of New York City, which is $1.2 \%$, likely because of the large number of foreign born inhabitants. Accordingly, the aim of the present study was to characterize the patients with chronic hepatitis $\mathrm{B}$ at a community hospital in Brooklyn, New York.
\end{abstract}

Methods: A retrospective chart review of patients with chronic hepatitis B seen in the hepatology clinic from 2004 to 2013 . Data on country of origin, mode of transmission, hepatitis B serology and genotype, and liver histology were collected.

Results: Two-hundred and forty-seven patients with chronic hepatitis B of whom 137 were men and 110 were women, were identified. The average age was 46 years. The most common route of infection was sexual, followed by horizontal transmission. Genotype A was the most prevalent. Of all the patients, 40 (16\%) met criteria for treatment; although most patients had adequate viral suppression, none seroconverted.

Conclusion: Chronic hepatitis B is one of the conditions commonly identified at a hepatology clinic in the North Brooklyn community; thus, screening practices to diagnose the infection and limit transmission by vaccination and education are warranted.

\section{Introduction}

Around the world, over 248 million people are infected with the chronic hepatitis B virus (HBV); of these, approximately 600,000 die yearly of its consequences. The highest prevalence of hepatitis $B$ viral infection is in Asia and Sub-Saharan Africa where most patients become infected in early childhood, and where $5-10 \%$ of the population is chronically infected $[1,2]$. It has been reported that the prevalence of chronic hepatitis B in New York City (NYC) is $1.2 \%$, which is greater than in the rest of the United States, in which it is $0.3-0.5 \%$, considered to be mainly because of a high percentage of foreign born persons in the city, and where $36 \%$ of its inhabitants are foreign born nationals compared to $11 \%$ nationwide [3-7].

Accordingly, the aim of this study was to characterize the patients with chronic hepatitis B attended in a community hospital located in northern Brooklyn, and that serves a substantial number of patients from different parts of the world.

\section{Patients and methods}

This study was a retrospective review of charts from patients who had been seen at the hepatology clinic at least once between 2004 to 2013, and whose medical records had been coded by ICD 10 as chronic hepatitis B. The study was approved by the Institutional Review Board.

\section{Results}

Two-hundred and forty-seven patients were identified. The demographics are given in Table 1 . The majority of patients was from
Central and South America. The most common mode of transmission was unprotected sexual intercourse; however, in 126 patients the route of transmission was not documented. Comorbid conditions included hypertension, diabetes mellitus, and human immunodeficiency virus infection.

Data related to the HBV infection, and liver disease are documented in Table 2 and Table 3.

Fifty-five (23\%) patients had high level of replication as suggested by HBV DNA greater than 20,000 IU/ml. One patient was co-infected with the delta hepatitis virus. In the majority of patients, serum activity of liver transaminases was below two times the upper limit of normal, considered to reflect minimal or no inflammatory activity. Twenty-two of 247 (10\%) had a liver biopsy performed.

Mutations were detected in 107 of 247 (43.3\%) patients, most of whom had a reactive anti-HBe antibody (96/107). A group of patients had a high serum HBV DNA in conjunction with anti-HBe antibody and a precore mutation (13/247), most of which were HBV genotype D.

Correspondence to: Dalia Mahmoud, Division of Gastroenterology, NYC Health+Hospitals, Woodhull, Brooklyn, NY, USA, Tel: +1 718-963-8000; E-mail: Dalia.Mahmoud-Hassan-Elamin@nychhc.org

Key words: chronic hepatitis B, hepatology clinic, anti-HBe antibody, viral hepatitis, prevent disease transmission

Received: February 14, 2018; Accepted: February 21, 2018; Published: February 25,2018 
Table 1. Demographics.

\begin{tabular}{|l|l|}
\hline Age & $20-82$ (Average 46) \\
\hline Gender & $137(55 \%)$ \\
Male & $110(45 \%)$ \\
Female & $13(5.2 \%)$ \\
\hline Region of Birth & $49(19.3 \%)$ \\
USA & $18(7.3 \%)$ \\
Africa & $12(4.8 \%)$ \\
Asia & $64(25.9 \%)$ \\
Europe & $91(37 \%)$ \\
South/Central America & \\
Unknown & $10(4 \%)$ \\
\hline Co-morbidities & $27(10.9 \%)$ \\
HIV & $45(18.2 \%)$ \\
Diabetes mellitus & \\
Hypertension & $10(4 \%)$ \\
\hline Route of transmission & $45(18.2 \%)$ \\
IVDU & $18(7.2 \%)$ \\
Sexual & $15(6.0 \%)$ \\
Vertical & $33(13.3 \%)$ \\
Blood Transfusions & $22(8.9 \%)$ \\
Needles/Tattoos & $126(51.0 \%)$ \\
Multiple & \\
Unknown/not documented & \\
\hline HIV: human immunodeficiency virus & \\
IVDU: intravenous drug use & \\
\hline
\end{tabular}

Table 2. Hepatitis B virus infection characteristics

\begin{tabular}{|c|c|}
\hline Genotype & $N=141 / 247(57 \%)$ \\
\hline A & $73(51 \%)$ \\
\hline B & $2(1.4 \%)$ \\
\hline C & $1(0.7 \%)$ \\
\hline D & $36(25 \%)$ \\
\hline $\mathbf{E}$ & $26(18.4 \%)$ \\
\hline $\mathbf{F}$ & $2(1.4 \%)$ \\
\hline $\mathbf{G}$ & $1(0.7 \%)$ \\
\hline $\begin{array}{l}\text { Mutations } \\
\text { Detected } \\
\text { Not detected }\end{array}$ & $\begin{array}{l}\mathbf{N}=\mathbf{1 4 1} / \mathbf{2 4 7}(\mathbf{5 7 \%}) \\
107(75.8 \%) \\
34(24.2 \%)\end{array}$ \\
\hline $\begin{array}{l}\text { HBV DNA }(\mathrm{IU} / \mathrm{ml}) \\
\quad<\mathbf{2 , 0 0 0} \\
\mathbf{2 , 0 0 0 - 2 0 , 0 0 0} \\
>\mathbf{2 0 , 0 0 0}\end{array}$ & $\begin{array}{l}\mathbf{N}=\mathbf{2 3 8} / \mathbf{2 4 7}(\mathbf{9 6 . 3} \%) \\
124(52 \%) \\
59(24 \%) \\
55(23 \%)\end{array}$ \\
\hline $\begin{array}{l}\text { Transaminases (AST, ALT) } \\
\quad<\mathbf{2} \text { times ULN } \\
\quad>\mathbf{2} \text { times ULN }\end{array}$ & $\begin{array}{l}\mathbf{N}=\mathbf{2 4 7} \\
223(90.2 \%) \\
24(9.8 \%)\end{array}$ \\
\hline $\begin{array}{l}\text { Liver biopsy } \\
\text { Performed } \\
\text { Not performed }\end{array}$ & $\begin{array}{l}\mathbf{N}=\mathbf{2 4 7} \\
22(8.9 \%) \\
225(91.1 \%)\end{array}$ \\
\hline \multicolumn{2}{|c|}{$\begin{array}{l}\mathrm{N}=\text { number and percentage of patients with available data } \\
\text { AST: aspartate transaminase } \\
\text { ALT: alanine transaminase } \\
\text { ULN: upper limit of normal }\end{array}$} \\
\hline
\end{tabular}

Table 3. Treated patients $(\mathrm{N}=40)$.

\begin{tabular}{|l|l|}
\hline $\begin{array}{l}\text { HBeag } \\
\text { positive } \\
\text { negative }\end{array}$ & $12(30 \%)$ \\
\hline HBV DNA (IU/mI) & $28(70 \%)$ \\
$<2,000$ & \\
$2,000-20,000$ & $6(15 \%)$ \\
$>20,000$ & $11(27 \%)$ \\
\hline Treatment & $23(57 \%)$ \\
Antivirals & \\
Pegylated interferon & $30(75 \%)$ \\
Antivirals and pegylated interferon & $9(22 \%)$ \\
\hline
\end{tabular}

The different phases of hepatitis B infection in our subjects are represented in Table 4. Most of the patients were classified as having $\mathrm{HBe}$ antigen (HBeAg) negative chronic hepatitis.
Forty of the 247 (16\%) patients met criteria for treatment; of these, twelve patients were $\mathrm{HBeAg}$ positive and $23 \mathrm{had}$ a viral load of more than $20,000 \mathrm{IU} / \mathrm{ml}$. Thirty were treated with oral antiviral agents and nine with pegylated interferon. One patient was co-infected with hepatitis $\mathrm{C}$ and HIV viri; he was treated for the former in association with sustained virological response, and for the latter, he received highly active antiretroviral therapy (Table 3). None of the patients treated seroconverted from $\mathrm{HBeAg}$ to anti-HBe antibody, or lost surface antigen, although 30 (75\%) did have adequate viral suppression.

Eleven of the 247 patients (4.4\%) had documented complications related to chronic hepatitis B including hepatocellular carcinoma, nephrotic syndrome, and findings consistent with cirrhosis.

\section{Discussion and Conclusion}

In this study, patients with chronic hepatitis B came from different continents, consistent with the diverse population served by the hospital; however, the lack of documented country of origin in the medical records is a limitation to our interpretation. The most frequent genotype identified was $\mathrm{A}$, consistent with the geographic area from which the majority of the patients came, Central and South America, a reflection of the origin of patients who reside in the neighborhoods around the institution. Only sixteen percent of the patients met criteria for treatment; however, although treatment is not recommended for all patients, the identification of chronic hepatitis B is an important public health finding that provides support for screening for this chronic infection, and for the provision of standard of care to this type of patients. In addition, vaccination efforts to prevent infection of close contacts would be a direct result from identifying patients with chronic hepatitis $B$.

In 150 patients, the route of transmission was not documented. This finding may suggest that patients might have had subclinical hepatitis B virus infection and were not aware at the time of diagnosis of the factors or behaviors that might have facilitated the infection. In this context, public health care practices, including lay injectors, may also contribute to the unrecognized spread of this (and others) viral infections. Furthermore, the lack of knowledge of the risk factors associated with acquisition of viral hepatitis is likely a barrier to the containment of the spread of viral hepatitis. In this regard, the fact that the most common mode of transmission in this study was sexual transmission supports the idea that improved education regarding risk factors is pivotal in the control of chronic hepatitis $B$, an infection that can be prevented by vaccination. In addition, limited information obtained in the medical interview may contribute to the lack of data in the charts, suggesting that the inclusion of templates into the electronic medical records may help physicians and other health care providers to improve documentation.

Hepatitis B virus is classified into eight genotypes (A-H) according to phylogenetic analysis [8]. The most common genotypes in this study were A, D and E, which are the most common in North America, southern Europe, Middle East and sub-Saharan Africa [9]. The patients with high levels of serum HBV DNA in association with a pre-core mutation and negative anti-HBe antibody were infected with genotype D mostly, consistent with existing literature [10].

Chronic HBV infection is divided into four phases: immune tolerant, immune clearance (or activation), inactive carrier state, and HBeAg negative chronic hepatitis, as described in Table 4 [11-16]. Most of our patients fell in the latter category, followed by inactive carrier state. We note that 3 of the 4 patients in the immune tolerant phase exhibited piecemeal necrosis on liver histology, consistent with the finding that a substantial proportion of patients have inflammatory 
Table 4. Phase of hepatitis B infection $(\mathrm{N}=222)$.

\begin{tabular}{|c|c|c|c|c|}
\hline & IT & IC & Inactive Carrier & HBeag negative chronic hepatitis \\
\hline Number of patients & $18(7 \%)$ & $6(2.4 \%)$ & $120(48 \%)$ & $78(31 \%)$ \\
\hline Number of biopsies & 4 & 0 & 4 & 13 \\
\hline Histology & $\begin{array}{l}\text { - } 4 / 4 \text { chronic hepatitis } \\
\text { - } 3 / 4 \text { piecemeal necrosis and } \\
\text { lobular activity }\end{array}$ & & $\begin{array}{l}\text { - } 3 / 4 \text { chronic hepatitis } \\
\text { - } 1 / 4 \text { piecemeal necrosis } \\
\text { - } 3 / 4 \text { lobular activity }\end{array}$ & $\begin{array}{l}\text { - } 9 / 13 \text { chronic hepatitis } \\
\text { - } 7 / 13 \text { piecemeal necrosis } \\
\text { - } 4 / 13 \text { fibrosis }\end{array}$ \\
\hline
\end{tabular}

IT: immune tolerant phase: high levels of HBV replication reflected by elevated serum DNA levels, positive HBeag, and normal transaminases suggestive of absence of disease activity IC: immune clearance phase: immune activation against HBV associated with elevated liver enzymes, loss of HBeag and development of anti-HBe

Inactive carrier: undetectable or low levels of HBV with normal serum activity of transaminases

HBeag-negative chronic hepatitis: chronic inflammation with fluctuating levels of HBV replication and serum transaminases (11-16)

changes in that phase despite normal serum activity of liver associated transaminases. As expected, most of the activity in the available liver histology was noted in patients in the reactivation, HBeag negative chronic hepatitis, as episodes of hepatitis flares are associated with substantial inflammatory activity [11-16].

The progression to cirrhosis and hepatocellular carcinoma differs by geographic regions and by degree of replication and serology $[4,11,18,19]$. Our study was not longitudinal; thus, identification long term complications of chronic hepatitis B in the cohort examined was not possible.

There are treatment guidelines, recently updated, to manage patients with chronic hepatitis B 20]. There are several pharmacological options that include pegylated interferon and oral antiviral agents [21]. The decision to treat, choice of agent, as well as the length of treatment are based on several factors that include status of $\mathrm{HBeAg}$, serum activity of liver associated transaminases, presence of cirrhosis (compensated versus decompensated), prior treatment, genotype, and co-morbidities [21,22.; not all patients with chronic hepatitis B meet criteria for treatment. In our patients, treatment was not associated with seroconversion from HBeag to antiHBe antibody, or with loss of surface antigen and development of anti-hepatitis B surface antibody (HBsab) in any of the patients. At present, the rate of success in regard to seroconversion is limited, therefore, the development of drugs that lead to the cure of chronic hepatitis B is an area of intense effort. However, the treatment of patients with decompensated liver disease from chronic hepatitis B is associated with marked improvement in liver function and resolution of complications including ascites; thus, it is important to identify this group of patients, not found in our cohort, for treatment.

In summary, chronic hepatitis B is a chronic infection carried by patients attended in the hepatology clinic of the hospital and hence, in the community of northern Brooklyn, the source of most of the referrals to the institution. Educational efforts to raise awareness on hepatitis B viral infection, its modes of transmission, along with the exhortation of physicians and other health care providers to screen high risk populations will result in identification of patients and in vaccination campaigns to prevent disease transmission.

\section{References}

1. http://www.who.int/mediacentre/factsheets/fs204/en/

2. http://www.census.gov/popest/data/state/totals/2013/index.html

3. Perz JF, Armstrong GL, Farrington LA, Hutin YJ, Bell BP (2006) The contributions of hepatitis $\mathrm{B}$ virus and hepatitis $\mathrm{C}$ virus infections to cirrhosis and primary liver cancer worldwide. J Hepatol 45: 529-538. [Crossref]

4. Weinbaum CM, Mast EE, Ward JW (2009) CDC Recommendations for identification and public health management of persons with chronic hepatitis B virus infection. Hepatology 49: S28-S34. [Crossref]

5. Kowdley KV, Wang CC, Welch S, Roberts H, Brosgart CL (2012) Prevalence of chronic hepatitis B among foreign-born persons living in the United States by country of origin. Hepatology 56: 422-433. [Crossref]
6. Department of Health and Mental Hygiene, Division of Disease Control, Bureau of Communicable Diseases Health (2008-2009) Hepatitis A, B and C Surveillance Report. New York City, USA.

7. France AM, Bornschlege K, Lazaroff J, Kennedy J, Balter S (2008) Estimating the Prevalence of Chronic Hepatitis B Virus Infection-New York City, 2008. J Urban Health 89: 373-383. [Crossref]

8. Stuyver L, De Gendt S, Van Geyt C, Zoulim F, Fried M, et al. (2000) A new genotype of hepatitis B virus: complete genome and phylogenetic relatedness. J Gen Virol 81: 67-74. [Crossref]

9. Norder H, Hammas B, Lee SD, Bile K, Couroucé AM, et al. (1993) Genetic relatedness of hepatitis B viral strains of diverse geographical origin and natural variations in the primary structure of the surface antigen. A Magnius LOSOJ Gen Virol 74: 1341-1348. [Crossef]

10. Eloy AM, Moreira RC, Lemos MF, Silva JL, Coêlho MR (2013) Hepatitis B virus in the State of Alagoas, Brazil: genotypes characterization and mutations of the precore and basal core promoter regions. Braz J Infect Dis 17: 704-706. [Crossref]

11. Chang MH, Hwang LY, Hsu HC, Lee CY, Beasley RP (1988) Prospective study of asymptomatic HBsAg carrier children infected in the perinatal period: clinical and liver histologic studies. Hepatology 8: 374-377. [Crossref]

12. Lok AS, Lai CL (1988) A longitudinal follow-up of asymptomatic hepatitis B surface antigen-positive Chinese children. Hepatology 8: 1130-1133. [Crossref]

13. Liaw YF, Chu CM, Lin DY, Sheen IS, Yang CY, et al. (1984) Age-specific prevalence and significance of hepatitis B e antigen and antibody in chronic hepatitis B virus infection in Taiwan: a comparison among asymptomatic carriers, chronic hepatitis, liver cirrhosis, and hepatocellular carcinoma. J Med Virol 13: 385-391. [Crossref]

14. Lok AS, Lai CL, Wu PC, Leung EK, Lam TS (1987) Spontaneous hepatitis B e antigen to antibody seroconversion and reversion in Chinese patients with chronic hepatitis B virus infection. Gastroenterology 92: 1839-1843. [Crossref]

15. Chu CM, Chen YC, Tai DI, Liaw YF (2010) Level of hepatitis B virus DNA in inactive carriers with persistently normal levels of alanine aminotransferase. Clin Gastroenterol Hepatol 8: 535-540. [Crossref]

16. Lok AS, Hadziyannis SJ, Weller IV, Karvountzis MG, Monjardino J, et al. (1984) Contribution of low level HBV replication to continuing inflammatory activity in patients with anti-HBe positive chronic hepatitis B virus infection. Gut 25: 1283-1287. [Crossref]

17. Carman WF, Jacyna MR, Hadziyannis S, Karayiannis P, McGarvey MJ, et al. (1989) Mutation preventing formation of hepatitis $\mathrm{B}$ e antigen in patients with chronic hepatitis $\mathrm{B}$ infection. Lancet 2: 588-591. [Crossref]

18. Alter MJ, Hadler SC, Margolis HS, Alexander WJ, Hu PY, et al. (1990) The changing epidemiology of hepatitis B in the United States. Need for alternative vaccination strategies. JAMA 263: 1218-1222. [Crossref]

19. Fattovich G, Bortolotti F, Donato F (2008) Natural history of chronic hepatitis B: Special emphasis on disease progression and prognostic factors. J Hepatol 48: 335352. [Crossref]

20. Lok AS, McMahon BJ (2009) Chronic Hepatitis B: Update 2009. AASLD Practice Guideline Update. Hepatology 50: 661-662. [Crossref]

21. Pan CQ, Zhang JX (2005) Natural History and Clinical Consequences of Hepatitis B Virus Infection. Int J Med Sci 2: 36-40. [Crossref]

22. Terrault NA, Bzowej NH, Chang KM, Hwang JP, Jonas MM, et al. (2016) AASLD guidelines for treatment of chronic hepatitis B. Hepatology 63: 261-283. [Crossref]

Copyright: (C2018 Mahmoud D. This is an open-access article distributed under the terms of the Creative Commons Attribution License, which permits unrestricted use, distribution, and reproduction in any medium, provided the original author and source are credited. 